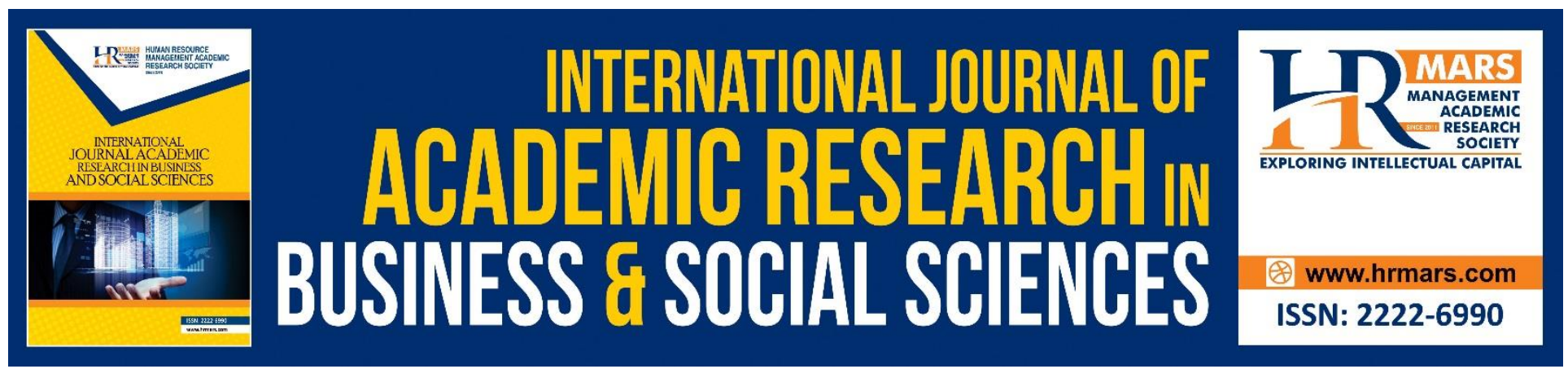

\title{
Young People Decision in Selection of Higher Education Institution: Theory of Planned Behavior Perspective
}

Siti Nurshahidah Binti Sah Allam, Mohd Sufiean Hassan, Abdul Rauf Hj. Ridzuan, Rosilawati Sultan Mohideen, Siti Nur Farrah Faadiah Ab. Ghani, Khurul Ain Mahasan

To Link this Article: http://dx.doi.org/10.6007/IJARBSS/v8-i11/4890

DOI: $10.6007 /$ IJARBSS/v8-i11/4890

Received: 21 Sept 2018, Revised: 17 Oct 2018, Accepted: 29 Oct 2018

Published Online: 24 Nov 2018

In-Text Citation: (Allam et al., 2018)

To Cite this Article: Allam, S. N. B. S., Hassan, M. S., Ridzuan, A. R. H., Mohideen, R. S., Ghani, S. N. F. F. A., \& Mahasan, K. A. (2018). Young People Decision in Selection of Higher Education Institution: Theory of Planned Behavior Perspective. International Journal of Academic Research in Business and Social Sciences, 8(11), 138-150.

Copyright: (C) 2018 The Author(s)

Published by Human Resource Management Academic Research Society (www.hrmars.com)

This article is published under the Creative Commons Attribution (CC BY 4.0) license. Anyone may reproduce, distribute, translate and create derivative works of this article (for both commercial and non-commercial purposes), subject to full attribution to the original publication and authors. The full terms of this license may be seen

at: http://creativecommons.org/licences/by/4.0/legalcode

Vol. 8, No. 11, 2018, Pg. 138 - 150

http://hrmars.com/index.php/pages/detail/IJARBSS

JOURNAL HOMEPAGE

Full Terms \& Conditions of access and use can be found at http://hrmars.com/index.php/pages/detail/publication-ethics 


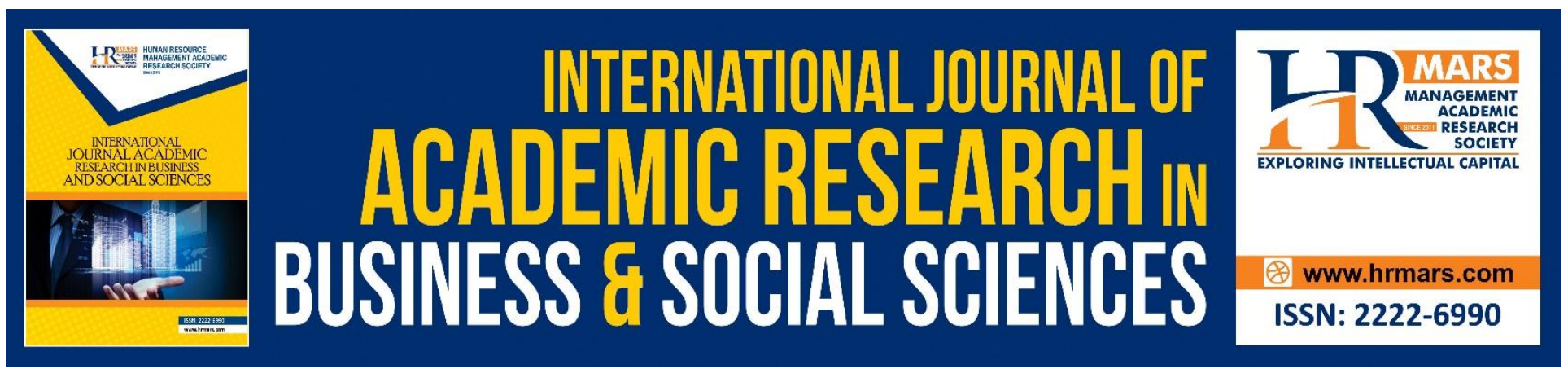

\title{
Young People Decision in Selection of Higher Education Institution: Theory of Planned Behavior Perspective
}

\author{
Siti Nurshahidah Binti Sah Allam \\ Mohd Sufiean Hassan, Dr. Abdul Rauf Hj. Ridzuan, Rosilawati \\ Sultan Mohideen, Siti Nur Farrah Faadiah Ab. Ghani, Khurul Ain \\ Mahasan \\ UiTM, Melaka, Malaysia
}

\begin{abstract}
This paper aims to examine relationship of intention behaviour, subjective norms and perceived behavioural control in Theory of Planned Behavior (TPB) perspective. The study adopted a survey to collect data among $400 \mathrm{HEl}$ students. The findings show that there is a significant relationship between intention behavior and perceived behavior control with selection to IPT, while subjective norm have no significant relationship. Apart from that, this study confirm that intention behaviour and perceived behavior control contribute strong predictor to young people decision in selection of HEl. This study contributes new idea of TPB perspective and young people decision in selection of HEl.
\end{abstract}

Keywords: Theory of Planned Behavior (TPB), intention behavior, subjective norm, perceive behavior control, Higher Education Institutions (HEI)

\section{Introduction}

In line with the development of technology and government policy in the National Key Result Areas (NKRAs) to increase access and equity in tertiary education to the young people. In order to understand young people decision in selection to HEI, this study adopted constructs frrom Theory of Planned Behaviour (TPB) which consist of intention behaviour, subjective norms and perceived behavioural control (Azjen, 1985; Azjen, 1991). This research bring new perspective of intention behavior in TPB, where attitude as claim by many researcher as first determinant factors of willingness to engage certain behavior but we believe that intention behavior the first determinant factors of planned behaviour among young people. This idea supported by P. A. M. van Lange, (2012) who reported that intention is the immediate predecessor of behavior and it is connected toward subjective norms and perceive behavior control. Apart from that subjective norms also predicted to 
influence young people decision in selection to $\mathrm{HEl}$. The young people intention to pursue education in $\mathrm{HEl}$ reinforce by subjective norms which refers to the degree to which a person has a favorable or unfavorable evaluation of others toward their intention behavior (Ajzen 1986). In this context, the more stronger subjective norms unit such as family, school and friends emphasis young people intention to pursue study and the more stronger behavior towards intention behavior (Safeena et al, 2013).

The resources and opportunities available to a young people must up to some degree prescription the possibility of behavioural achievement (Netemeyer, \& Ryn 1991). In the context of this study, perceived behavioural control is empowered with the availability of HEI information as an opportunity domain for individuals accessing $\mathrm{HEl}$ information. This opportunity is reinforced by the availability of information on HEI online via social media (Mahyarni, 2013). This dissemination of information is effective with the use of social media, in which the medium offers interactive features such as interactive (Andriani Kusumawati, 2010), ease of use, and interactive (Mary Madden, 2017), a wide range of communication approaches target audience and dissemination of more effective information (Koo, 2015).

Hence, this study was conducted to examine the impact of of intention behaviour, subjective norms and perceived behavioural control in Theory of Planned Behaviour (TPB) perspective in young peopple decision selection among $407 \mathrm{HEl}$ students through survey. This study focuses on assessing the correlation between TPB constructs such as intention behaviour, subjective norms and perceived behavioral control factors with the selection of $\mathrm{HEI}$.

\section{Perspective of The Theory of Planned Behaviour (TPB) With The Use Of Social Media Accessibility To HEls}

The planned behavioral theory is an extension of the Theory of Reasoned Action proposed by Azjen \& Fishbein in 1985 (Azjen, 1985; Azjen, 1991). Theory of Planned Behavioral or TPB is a theory that predicts intentional behavior, for believing that behavior action can be planned (Safeena et al, 2013).

Figure 1: Theory of Planned Behaviour

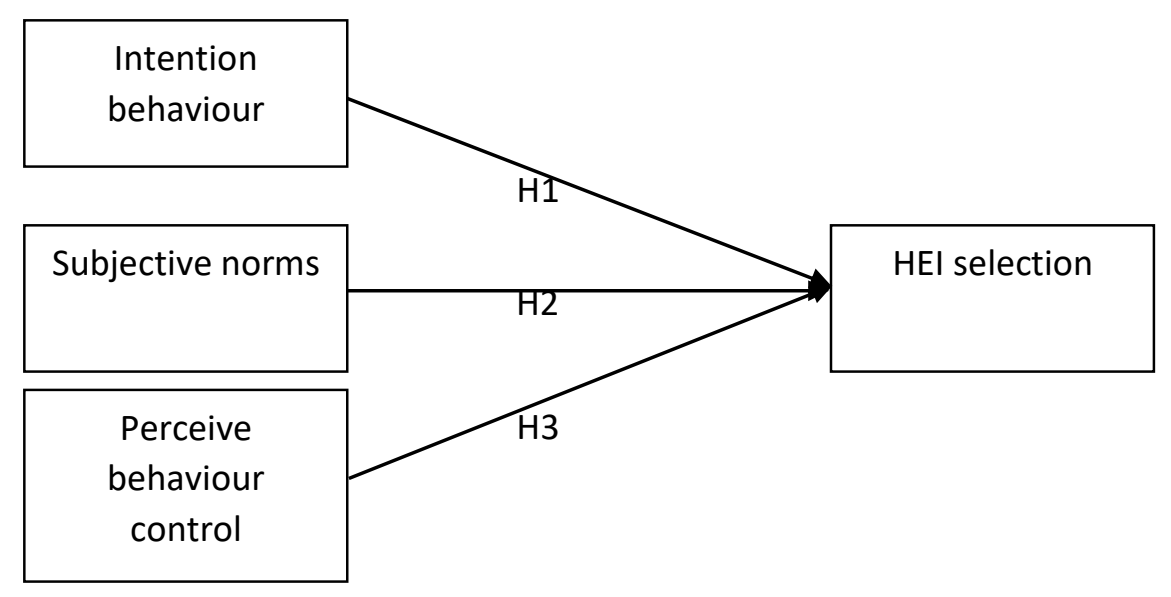




\section{Intention Behavior}

This research bring new perspective of intention behavior in TPB, where attitude as claim by many researcher as first determinant factors of willingness to engage certain behavior but we believe that intention behavior the first determinant factors of planned behaviour among young people. This idea supported by Lange, (2012) who reported that intention is the immediate predecessor of behavior and it is connected toward subjective norms and perceive behavior control. The stronger a young people intention in pursuing study, the more the individual effort is expected to try, and hence the greater the probability that the behavior will actually be performed, that is, the choice to $\mathrm{HEI}$ only takes place if there is an element of intent to pursue education in HEI (Ajzen 1986). This intention is empowered with the support and advice of socialization agents such as family, teachers and friends and when this intent is supported, behavior control exists to encourage individuals to achieve the intention to HEI through information retrieval from social media. According to Koo (2015), social media users think this medium offers a mobile search engine, which is information retrieval performed everywhere and at any time. Furthermore, seeking information through social media offers high reliability, ease of information and the hassle of finding information online is low. From this review, this study states the hypothesis that:

H1. There is a positive significant relationship between intention behaviour and HEl selection through social media use.

\section{Subjective Norms}

The young people intention to pursue education in HEI reinforce by subjective norms which refers to the degree to which a person has a favorable or unfavorable evaluation of others toward their intention behavior (Ajzen, 1986). The notion of subjective norms continuously refers to individual perceptions that people who are important to him in thinking whether the individual should or should not conduct a behavior in a particular intention (Ajzen, 1985). In this context, the more stronger subjective norms unit such as family, school and friends emphasis young people intention to pursue study and the more stronger behavior towards intention behavior (Safeena et al, 2013). This idea supported by Mahyarni (2013) who claimded that the more significance of subjective norms unit to a young people, the more intention behavior being approved. There is an evidence reported that subjective norms unit causes lower intention behavior such as family socio economy (Davis, Saunders \& Williams 2002), availability HEI information in former school (Kwon, \& Wen 2010) and group of friends who have same intention behaviour. From this review, this study states the hypothesis that: H2. There is a positive significant relationship between subjective norms influence HEl selection through social media use.

\section{Perceive Behavioural Control}

Perceived behavioural control as the ability to predict behaviour based on skills, resources, access to information, emotions and opportunity to perform intention behaviour (Ajzen 1986). The resources and opportunities available to a young people must up to some degree prescription the possibility of behavioural achievement (Netemeyer, \& Ryn 1991). In the context of this study, perceived behavioural control is empowered with the availability of $\mathrm{HEl}$ information as an opportunity domain for individuals accessing HEl information. This opportunity is reinforced by the availability of 
information on HEI online via social media (Mahyarni, 2013). Features of social media who offer ease of use (Ika Destiana, 2013), interactive sources and wider social network (Omar, 2014), more effective communication than conventional media (Hamzah, 2010) and gain social support (Hayes, 2016) may contribute to an opportunity for individuals accessing HEI information (Vromen, Xenos \& Loader 2014). From this review, this study states the hypothesis that:

H3. There is a positive significant relationship between perceive behavior control influence HEI selection through social media use.

To answer the hypothesis, this study draws on systematic methods for data collection and analysis.

\section{Research Methodology And Procedure}

This study focuses on assessing correlation between behavioral intentions, subjective norms and behavioral control factors with accessibility to HEls. This study uses quantitative methods as a method of study. This is because most social media studies, researchers use quantitative methods as their research methods such as (Riley 2012; Cohen, \& Zeira 2016; Nasir, Rosenthal \& Moore 2011). Hence, this method is selected based on literature review of social media impact on accessibility to HEIs.

\section{Population Sample}

The sampling of this study was selected among students of IPT in Malacca by purposive sampling of 18 years old or above or SPM, STPM, Matriculation and Diploma. The first diploma and first degree students were purposively sampling (purposive sampling) selected from the College of Islamic University of Melaka (KUIM) with a population of 5545 students, and Agrosains University College of Malaysia (UCAM) with a population of 2700 students.

Table 1: Sampling

\begin{tabular}{|llll|}
\hline IPTS & Population & Percentage (\%) & Sample Size \\
KUIM & 5545 & 67 & 268 \\
UCAM & 2700 & 33 & 132 \\
JUMLAH & 8245 & 100 & 400 \\
\hline
\end{tabular}

\section{Research Methodology}

This study uses survey or survey methodology to obtain information. In this method, a questionnaire will be designed in accordance with the topic and objective of the study. The questionnaire will be distributed purposely to selected respondents. Descriptive research (survey) was used in this study. According to Sidek Mohd Noah (2002) a descriptive study design is usually carried out to provide systematic information on the facts and characteristics of a population or field of interest in fact and accuracy. 
INTERNATIONAL JOURNAL OF ACADEMIC RESEARCH IN BUSINESS AND SOCIAL SCIENCES

Vol. 8, No. 11, Nov, 2018, E-ISSN: 2222-6990 @ 2018 HRMARS

\section{Research Findings}

The study of 407 first semester students in KUIM and UCAM found $52.6 \%$ of respondents were from rural areas and are active social media users with $96.3 \%$ use social media for more than 2 years.

Table 1: Research variable

\begin{tabular}{|c|c|}
\hline Variable & $\mathbf{N}(\%)$ \\
\hline \multicolumn{2}{|l|}{ Sex } \\
\hline male & $130(31.9)$ \\
\hline female & $277(68.1)$ \\
\hline \multicolumn{2}{|l|}{ Race } \\
\hline Malay & 395 (97.1) \\
\hline Chinese & $3(0.7)$ \\
\hline Indian & $2(0.5)$ \\
\hline Other & $7(1.7)$ \\
\hline \multicolumn{2}{|l|}{ Place of residence } \\
\hline Town & $193(47.4)$ \\
\hline Rural area & $214(52.6)$ \\
\hline \multicolumn{2}{|l|}{ Social Media Users } \\
\hline Yes & $405(99.5)$ \\
\hline No & $2(0.5)$ \\
\hline \multicolumn{2}{|l|}{ Use Social Media Experience } \\
\hline$<1$ year & $1(0.2)$ \\
\hline 1 to 2 years & $14(3.4)$ \\
\hline$>$ than 2 years & $392(96.3)$ \\
\hline \multicolumn{2}{|c|}{ Frequency of Use of Social Media } \\
\hline Several times a day & $347(85.3)$ \\
\hline Once in a day & $17(4.2)$ \\
\hline Several times a week & $28(6.9)$ \\
\hline Once in a week & $5(1.2)$ \\
\hline Several times in a month & $9(2.2)$ \\
\hline Once in a month & $1(0.2)$ \\
\hline \multicolumn{2}{|l|}{ Social Media Use Factor } \\
\hline Easy and user-friendly & $181(44.5)$ \\
\hline Communication & $103(25.3)$ \\
\hline Express feelings & $95(23.3)$ \\
\hline Influence of friends & $21(5.2)$ \\
\hline Free & $6(1.5)$ \\
\hline Other & $1(2.0)$ \\
\hline
\end{tabular}


Survey findings recorded $85.3 \%$ of respondents were using social media several times a day and driven by easy and user-friendly factors (44.5\%). Respondents also use social media for communication (25.3\%) and express (5.2\%). Overall, the findings proved that respondents used social media actively and this led to the measurement of the hypothesis of the study.

The measurement model in Table 3 shows a good fit-fit model with eight indicators ie $(X 2$, CMINDF, RMSEA, GFI, IFI, TLI, CFI and PGFI) as shown in Table 3. However, Marsh \& Hau (1996) recommends for getting a good value, the value of Chi-square $(X 2)$ is divided by the degree of freedom $(\mathrm{df}=100)$ to evaluate the fit-model compared to using $\chi 2$ (CMINDF). If CMINDF statistical statistics are less than 5, this indicates that the data match for validation factor analysis is good (Marsh \& Hau, 1996). CMINDF for this measurement model is less than the value of 5 (CMINDF = 1.925). This shows that the CFA model is good. In addition, the RMSEA value is .048 which is lower than .08 as suggested by Kline (2010). The index coefficient in Table 3 is greater than .90 shows a good model match (Byrne, 2010), and the PGFI value is greater than 0.5 (.684) which also shows a matched model with observed data (Hair, et al., 2010). Figure 1 shows the CFA Model for this study:

Table 3: Confirmatory Factor Analysis Planned behavior

\begin{tabular}{lllllllll}
\hline Description & $\chi^{2}$ & CMINDF & RMSEA & GFI & IFI & TLI & CFI & PGFI \\
\hline Model CFA & 213.724 & 1.925 & 0.048 & .943 & .976 & .970 & .976 & .684 \\
\hline
\end{tabular}


Figure 1: Confirmatory Factor Analysis Model (CFA) Planned Behavior

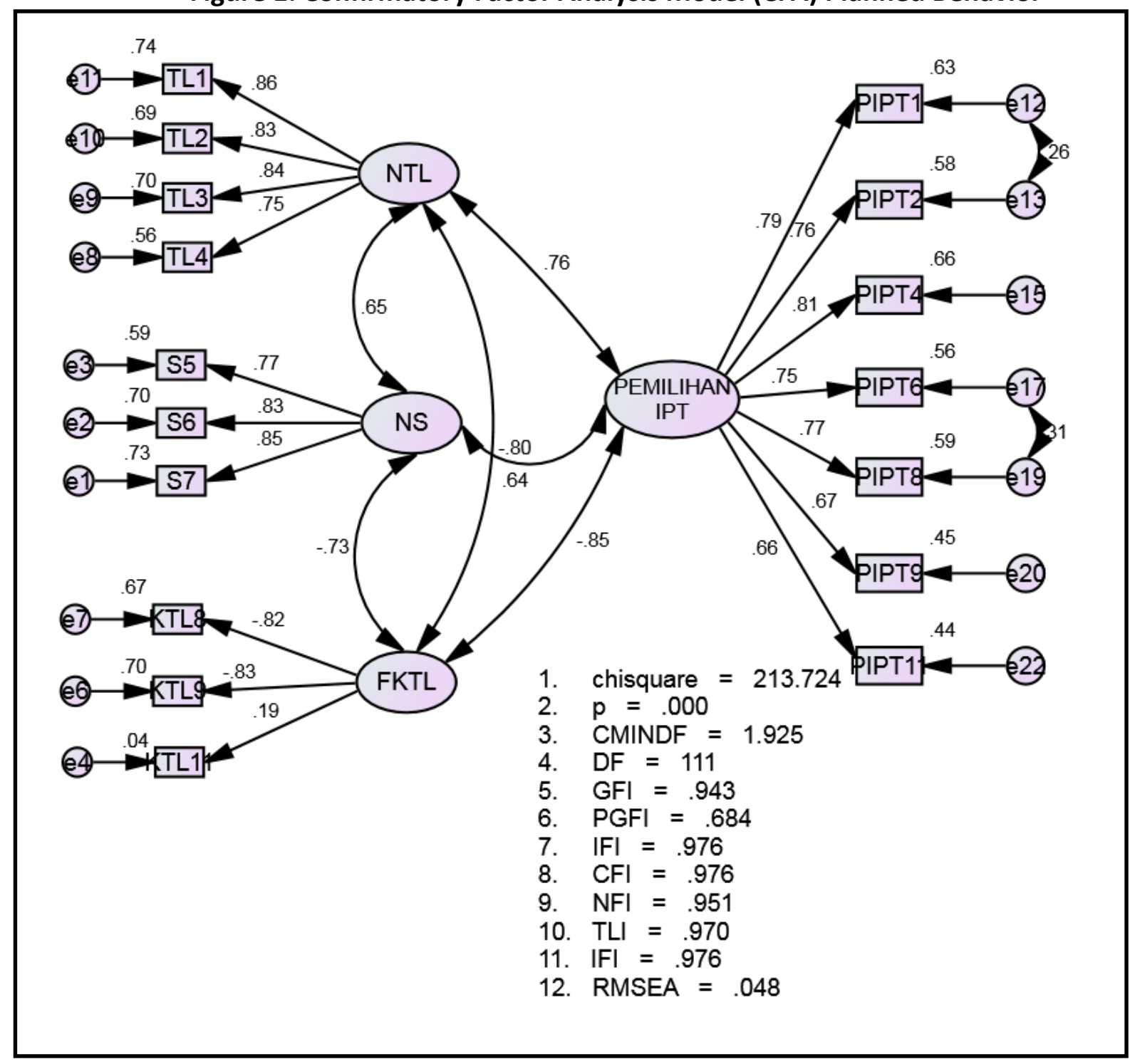


Figure 2: Structural Equation Modelling (SEM) Planned Behavior

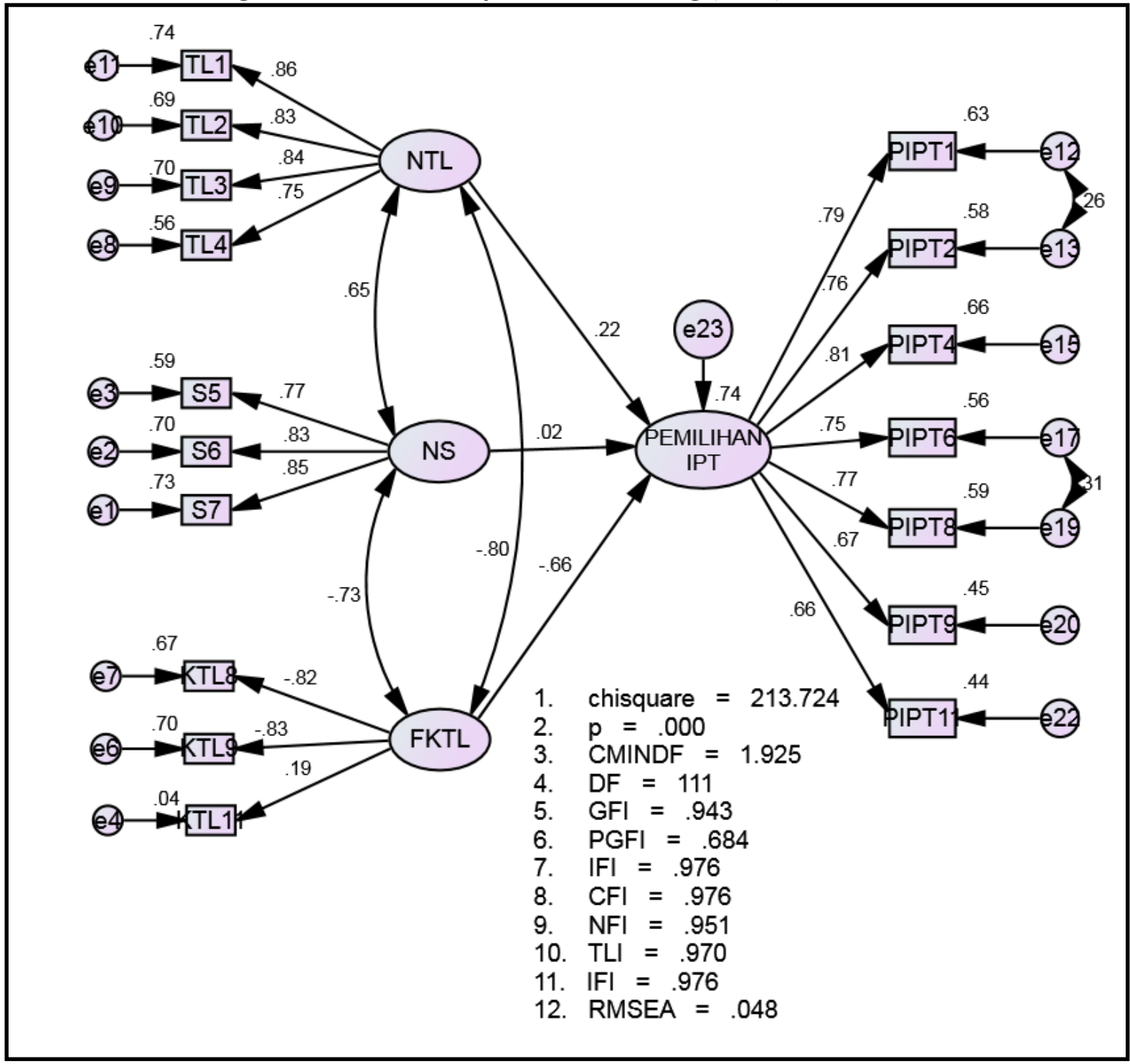

Table 4: Beta value for research variable

\begin{tabular}{|c|c|c|c|c|c|c|}
\hline Dependent variable & & Independent variable & $\begin{array}{l}\text { Standard } \\
(\beta)\end{array}$ & S.E. & C.R. & $P$ \\
\hline HEI Selection & $<---$ & Intention behaviour & .22 & .078 & 2.786 & .005 \\
\hline HEI Selection & $<---$ & Subjective norms & .02 & .054 & .232 & .816 \\
\hline HEI Selection & $<---$ & Perceive behaviour control & -.66 & .657 & -3.169 & .002 \\
\hline
\end{tabular}


INTERNATIONAL JOURNAL OF ACADEMIC RESEARCH IN BUSINESS AND SOCIAL SCIENCES

Vol. 8, No. 11, Nov, 2018, E-ISSN: 2222-6990 @ 2018 HRMARS

\section{Discussion}

The findings of 407 IPT students from KUIM and UCAM found that respondents were active social media users, where the experience of using social media more than 2 years was the majority compared to using social media less than 1 year. The frequency of social media use was studied and found semester 1 students from KUIM and UCAM login more than once a day to communicate and get social support from netizens. High social media usage among young people cause by features of social media who offer ease of use (Ika Destiana, 2013), interactive sources and wider social network (Omar, 2014), more effective communication than conventional media (Hamzah, 2010) and gain social support (Hayes, 2016).

To examine the young people decision in selection of $\mathrm{HEl}$, this study use to choose the Theory Planned Behavior (TPB) as a guide to the study frame. Since 1991, this theory is useful for predicting and understanding factors or motivations that affect the behavior of individuals as either positive or negative. In addition, TPB provides a study framework for learning behavior through behavioral intentions, subjective norms and behavioral controls. Most of the studies that applied TPB successfully demonstrated significant relationship between behavioral intention influencing actual behavior through subjective norms with the variables studied (Ha, 1998 \& Lin, 2004).

However, young people decision in selection of HEI from TPB perspective reported that there is an influence of intention behavior (path coefficient $=0.22, p<.005$ ) and perceived behavioral control (path coefficient $=-0.66, p<.002$ ) with the selection to HEls but the significant relationship is negative, while subjective norm (path coefficient $=0.02, p>.05$ ) has no significant relationship with the selection to HEls. This is true probably due to family economic factors.

Supporting this factor, the majority of respondents live in rural areas with average average and low income. This means that the intention to pursue education in HEls is less motivated by subjective referral groups especially for families due to financial constraints (Zaninia, 2015 \& Maio, 2015). There is a discrepancy between the findings of this study and the Planned Behavior theory which states that where the more positive norms are, the stronger the intention of behavior, the more negative the subjective norms are weakening the intention of behavior (Mahyarni, 2013). The lack of motivation of reference groups on behavioral intentions leads to individual tendencies seeking social support. Refer to Table 1, respondents use social media to express feelings or get social support from netizens. According to David A. Cole (2017), social support earned from netizens is capable of reducing feelings of stress and solving individual problems through chat app (cit chat).

In addition to the chat application, the interactive and easy-to-use features of social media make it appropriate for social support information through motivational sites, YouTube talk talks on Youtube and positive news feeds from social media users (Hayes, 2016). Directly, the use of social media is seen to replace the social function of parents / families in individual lives. This factor may also contribute to the function of the social reference group, where young people are no longer dependent on parents and teachers in solving problems because social media functions are more effective in providing social support to individuals. Upload status to social media accounts and be able to receive feedback, suggestions and advice from netizen in no time. Hence, the search for information to HEls is not continued and the use of social media is entertainment, finding friends and communicating (Hamzah, 2010 \& Omar, 2014). 
Furthermore, positive correlation relationships with moderate levels of behavior control factors with the selection to HEls exist because of information acquisition factors. In order to achieve the intention of the behavior, in addition to the support of subjective reference group references, resources or opportunities need to exist to express actual behavior (Mahyarni, 2013). This means that if the intentions of continuing studies exist, but the source or access to HEls information does not support the will of the individual, this positive intention tends to change to negative.

The search factor of HEls information on social media is the authenticity of information, information availability and easy-to-use (Akubugwo, 2013). Hence, HEls need to empower the use of social media as promoting multimedia media such as audio, video and mobile graphics and proper photo selection (Abu Elnasr E.Sobaih, 2016). In addition, the new millennium also features access and direct communication features between information owners and target groups, where feedback and questions get more efficient response than traditional media (Lee, 2017). In addition to the feedback, IPTs are proposed to promote financial assistance such as education loans, scholarships and allowances as well as incentives to prospective students choosing this IPT. This promotion is not only placed on the website but also shared on social media (Zaninia, 2015).

\section{Conclusions}

This study found that young people are active social media users and the factors of using social cause by features of social media who offer ease of use, interactive sources and wider social network, more effective communication than conventional media and gain social support. Young people decision in selection of $\mathrm{HEI}$ from TPB perspective reported that there is a significant relationship between intentional behavior and behavioral control with selection to IPT, while subjective norm reported have no significant relationship with the selection to HEls. Apart from that, this study confirm that intention behaviour and perceived behavior control contribute strong predictor to young people decision in selection of $\mathrm{HEl}$. Compared to earlier studies of intention behavior, subjective norms and behavior control have significant significant relationships and this study identifies several important factors such as family socio economy can affect young people intention behavior. This notion supported by previous study prove that the family economy level affects the selection to individual HEls, where financial constraints affect the intentions of individual behavior to continue their studies. When families are less motivated and encouraged, these young people seek social support in social media. Studies have shown that young people tend to use social media in solving problems rather than creating a discussion with the family. This is because apps and netizen support contribute more effective than functions of family in encouraging young people intention behavior. Furthermore, availability of HEls information in social media may increase the likelihood of young people using this medium to get information about faculty or program intended to purse study. Hence, this study suggests that HEls need to empower the role of social media as an effective promotional medium. Among them are information on social media featuring multimedia (audio, video and mobile graphics), immediate feedback for every question of student candidates and promotion of financial assistance is also disseminated in social media. Limitation of this study is a small selection of IPTs, so the findings of the study are not exhaustive and the medium tested is focused on social media without testing traditional media such as television and radio. 
INTERNATIONAL JOURNAL OF ACADEMIC RESEARCH IN BUSINESS AND SOCIAL SCIENCES

Vol. 8, No. 11, Nov, 2018, E-ISSN: 2222-6990 @ 2018 HRMARS

\section{Acknowledgement}

The authors thank the Student Affairs Department of KUIM and UCAM for assisting data collection of this research. Apart from that, findings of this study presented to the college management for the student intake unit attention.

\section{Corresponding Author}

Mohd Sufiean Hassan, Malaysia, Email: sufiean@kuim.edu.my

\section{References}

A.Miller, M. (2015). Why do people record and post illegal material? Excessive social media use, psychological disorder, or both? Computers in Human Behavior, 608-614.

Abu Elnasr E.Sobaih, M. A. (2016). To use or not to use? Social media in higher education in developing countries. Computers in Human Behavior, 296-305.

Akubugwo, I. \&. (2013). Influence of social media on social behaviour of post graduate students. A case study of Salford University, United Kingdom. Journal of Research \& Method in Education, 39-43.

Ana Radovic, T. G. (2017). Depressed adolescents' positive and negative use of social media. Journal of Adolessence, 5-15.

Andriani Kusumawati, V. K. (2010). University Marketing And Consumer Behaviour Concerns: The Shifting Preference Of University Selection Criteria In Indonesia. University If Wollongong Research Online, 1-17.

Bin, G. (2013). A Reasoned Action Perspective Of User Innovation: Model And Empirical Test. Industrial Marketing Management, 608-619.

Brian A. Primack, A. S. (2017). Social Media Use And Perceived Social Isolation Among Young Adults In The US. American Journal Of Preventive Medicine, 1-8.

Chaudhury, M. N. (2016). To Madrasahs Or Not To Madrashahs: The Question And Correlates Of Enrolment In Islamic School In Bangladesh. International Journal Of Education Development, 55-69.

David A. Cole, E. A. (2017). Online Social Support For Young People: Does It Recapitulate In Person Social Support: Can It Help. Computers In Human Behavior, 456-464.

Ha, C. L. (1998). The Theory Of Reasoned Action Applied To Brand Loyalty. Journal Of Product \& Brand Management, 51-61.

Hamzah, S. E. (2010). Media Sosial: Tinjauan Terhadap Laman Jaringan Sosial Dalam Talian Tempatan. Jurnal Pengajian Media Malaysia, 37-52.

Hayes, C. T. (2016). As Social Support: Relational Closeness, Automaticity And Interpreting Social Support From Paralinguistic Digital Affordances In Social Media. Computers In Human Behavior, 386-393.

Hyldegård, J. (2014). Young Learners' Use Of Social Media For Information Seeking: Exploring Core LIS Journals From 2010-2014. Library And Information Science Research E-Journal, 108-117.

Ika Destiana, A. S. (2013). Penerimaan Media Sosial: Kajian Dalam Kalangan Pelajar Universiti Di Palembang. Jurnal Komunikasi, 125-140. 
INTERNATIONAL JOURNAL OF ACADEMIC RESEARCH IN BUSINESS AND SOCIAL SCIENCES

Vol. 8, No. 11, Nov, 2018, E-ISSN: 2222-6990 @ 2018 HRMARS

Juceviciene, A. E. (2014). Factors Influencing School-Leavers Decision To Enrol In Higher Education. Procedia Social And Behavioral Sciences, 3983-3988.

Koo, N. C. (2015). The Use Of Social Media In Travel Information Search. Telematics And Informatics, 215-229.

Lee, J. W. (2017). When Does Individuals' Willing To Speak Out Increase On Social Media. Perceived Social Support And Perceived Power/Control . Computer In Human Behavior, 120-129.

Lin, H.-F. \&.-G. (2004). Perceptions Of Senior Managers Toward Knowledge-Sharing Behaviour. Management Decision, 108-25.

Liu, S. C.-K. (2010). Will Parental Influences Affect Career Choice? Evidence From Hospitality And Tourism Management Students In China. International Journal Of Contemporary Hospitality Management, 82-102.

Mahsood Shah, C. S. (2013). Factors Influencing Student Choice To Study At Private Higher Education Institutions . Quality Assurance In Education, 402-416.

Mahyarni, M. (2013). Theory Of Reasoned Action Dan Theory Of Planned Behavior (Sebuah Kajian Historis Tentang Perilaku). Jurnal El-Riyasah, 13-23.

Maio, G. L. (2015). Post High School Education Choices In Italy: An Empirical Analysis . Journal Of Applied Research In Higher Education, 229-242 .

Maizatul Haizan Mahbob, M. Z. (2011). Inovasi Perkhidmatan Awam Malaysia Melalui Pelaksanaan EKerajaan: Satu Kajian Empirik Tentang Penerimaan E-Servis Di Lembah Kelang. Jurnal Komunikasi, 1-16.

Mary Madden, A. L. (2017, July 7). Pew Research Center. Retrieved From Http://Www.Pewinternet.Org/2013/05/21/Teens-Social-Media-And-Privacy/.

Murad Ali, R. A.-A. (2016). Strengthening The Academic Usage Of Social Media: An Exploratory Study. Journal Of King Saud University: Computer And Information Sciences, 1-9.

Nimako, J. M. (2015). Critical Factors Underlying Students' Choice Institution For Graduate Programmes: Emperical Evidence From Ghana. International Journal Of Higher Education, 120-135.

Nurzatil Ismah Azizan, Z. D. (2015). Faktor-Faktor Yang Mendorong Pemilihan Institusi Pengajian Tinggi Di Kalangan Pelajar. E-Proceeding of The 2nd International Conference On Arabic Studies And Islamic Civilization, (Pp. 567-571). Kuala Lumpur, Malaysia: Worldconferences. Net.

Omar, F. I. (2014). Penerimaan Media Sosial Sebagai Medium Dakwah Dalam Kalangan Mahasiswa KUIS. E-Proceedings Of The Conference On Management And Muamalah, 1-11.

Pavica Sheldon, P. A. (2017). A Cross-Cultural Comparison Of Croatian And American Social Network Sites: Exploring Cultural Differences In Motives For Instagram Use. Computers In Human Behavior., 643-651.

Rutter R, R. S. (2016). Social Media Interaction, The University Brand And Recruitment Performan. Journal Of Business Research, 3096-3104.

Zanini, L. V. (2015). Away, But Not Too Far From Home. The Effects Of Financial Aid On University Enrolment Decisions. Economic Of Education Review, 91-109. 